\title{
Maize (Zea mays) Cultivated in Concrectionary Petric Plinthosol
}

\author{
Marcio Nikkel ${ }^{1} \&$ Saulo O. Lima ${ }^{1}$ \\ ${ }^{1}$ Plant Production Graduate Program, Universidade Federal do Tocantins, Gurupi, Brazil \\ Correspondence: Marcio Nikkel, Plant Production Graduate Program, Universidade Federal do Tocantins, \\ Gurupi, Tocantins, Brazil. Tel: 55-633-311-1604. E-mail: markel.26@hotmail.com
}

$\begin{array}{lcc}\text { Received: May 5, } 2019 & \text { Accepted: June 17, } 2019 & \text { Online Published: August 31, } 2019 \\ \text { doi:10.5539/jas.v11n14p131 } & \text { URL: https://doi.org/10.5539/jas.v11n14p131 }\end{array}$

This work is part of the thesis of the first author. The study was financed in part by the Coordenação de Aperfeiçoamento de Pessoal de Nivel Superior-Brasil (CAPES)-Finance Code 001.

\begin{abstract}
Soil with ironstone concretions, despite presenting disadvantages from the agronomic point of view, don't restrain its use in agriculture, livestock or forestry. However, more deeply and clear information about the behavior of crops of agricultural interest cultivated in this type of soil is absent. Due to the observation of agricultural stands with crops in this type of soil, the hypothesis that plinthite ironstone concretions in the soil interfered negatively in the development, at least in early stages, on crops of agro-economic interest. The objective was to verify the growth and development of maize (Zea mays) cultivated in soil with the presence of plinthite ironstone concretions and in the absence of them. Concretionary Petric Plinthosol were collected in the 0-0.20 m layer and part of the soil was sieved so that concretions larger than $3.10 \mathrm{~mm}$ in diameter were removed, thus leaving two treatments, soil with and without plinthite ironstone concretions. The experiment was then carried out and morphological and gas exchange evaluations were performed during their phenological phase. Maize grown in soil without ironstone concretions showed higher growth when compared to maize grown in soil with ironstone concretions, as well variation on gas exchange evaluation and leaf chlorophyll index. There were differences in the root and total dry matter values with more expressive value of the crops cultivated in soil without ironstone concretions. Therefore, it is concluded that plinthite ironstone concretions interfere in the development and growth of maize crop.
\end{abstract}

Keywords: concretions, plinthite ironstones, annual crops, root restriction, soil management

\section{Introduction}

Brazil is a strong producer of agricultural commodities, like soybean (Glycine max), maize (Zea mays) and sugar cane (Saccharum ssp.) (Sauer \& Leite, 2012) also one of the main exporters of cattle. Considered as the country's agricultural frontier, the MATOPIBA region, an acronym for the states of Maranhão, Tocantins, Piauí and Bahia (Dos Santos, 2018), presents many areas to be explored, whether native savanna or degraded pastures, with considerable variability of climate, rainfall index, relief and soil (Garcia \& Vieira Filho, 2017).

The main income of Tocantins state economy is agriculture and cattle raising, with soybean being the main agricultural crop (Silva \& Almeida, 2007). Crop rotation, together with permanent cover crops and minimum soil tillage, compose the basic principles of no-tillage system and so, avoid chemical, physical and biological loss in soil (Amorim Da Silva et al., 2018 ) and maize is an interesting species, both economic and manageable, to perform with soybean crop rotation.

One of the characteristics of the Tocantins' soils is the great quantity of Plinthsols (Secretaria do Planejamento e Orçamento do Tocantins [SEPLAN], 2015), which is characterized by the presence of plinthite, which is a formation from clay mixture, poor in organic carbon and rich in iron or iron and aluminium, with quartz grains and other minerals. After repeated cycles of wetting and dryness, plinthite undergoes vigorous consolidation, gaining irreversible petric aspect, denominated ironstones (United States Department of Agriculture [USDA], 1999; Chesworth, 2008; Oliveira, 2008; Dos Santos et al., 2018). Despite its undesirable agronomic characteristics (Azevedo \& Bueno, 2017), agricultural use is not an obstacle, with the cultivation of species of economic interest, such as soybean and beans (Phaseolus vulgaris), (Nikkel \& Lima, 2017) which require considerable agricultural mechanization. 
However, it is speculated that agricultural crops may be spending more photoassimilates in the root system, because the concretions of petroplinthite on the surface act as a restrictive environment for the free growth of the roots. Therefore, a study regarding the interaction of this soil and plants is justified. Therefore, the plant morphology comprises the study of the plant anatomy and reflects the ecological adaptation of the plants, due to the strong relation between form and its functioning, since it has an intense relation with the physiology. Benincasa (2003) says that growth analysis is still the most accessible and accurate way to evaluate growth and to understand the contribution of different physiological processes to plant behavior. From the growth data we can estimate causes of growth variations between plants submitted to different environments (Silva, Beltrão \& Amorim Neto, 2000; Peixoto, Cruz, \& Peixoto, 2011). Besides, the evaluation of physiological factors, like stomatal conductance, aims to observe the opening and closing of the stomata, since they can maximize the absorption of $\mathrm{CO}_{2}$ and minimize the losses of water vapor through transpiration. So, the measurement of gas exchanges, such as photosynthesis, stomatal conductance, respiration, internal rate of $\mathrm{CO}_{2}$, is a way of observing physiological responses of plants, which can be carried out locally, in situ, by means of portable photosynthesis meters (Long \& Bernacchi, 2003).

Therefore, the objective of this work is to evaluate, through morphological and physiological evaluations, the interference of plinthite ironstone concretions in the growth and development of maize.

\section{Methods}

\subsection{Area Description}

The study was conducted at the Federal University of Tocantins, Brazil, Gurupi University Campus, in the southern region of Tocantins state $\left(11^{\circ} 43^{\prime} \mathrm{S} / 49^{\circ} 04^{\prime} \mathrm{W}, 280 \mathrm{~m}\right.$ asl.). The climate of the region was classified according to the Köppen classification, Tropical Savanna (Aw) (Dubreuil, Fante, Planchon, \& Neto, 2018). The annual average temperature is $27^{\circ} \mathrm{C}$ and annual rainfall is $1.500 \mathrm{~mm}$, with rainy summer, dry winter and high water deficit between May and October. The soil, described and classified as the Concretionary Petric Plinthosol (Dos Santos et al., 2018) was collected in a savanna native area at surface layer of 0.0-0.20 m. Part of the soil was sieved in sieves with mesh up to $3.10 \mathrm{~mm}$ in order to separate the plinthite ironstone concretions, which corresponded to more than $65 \%$ of the soil mass. Table 1 shows values of the granulometry of the soil collected and its composition of concretions in the soil.

Table 1. Granulometry of Concrectionary Petric Plinthosol collected on layer 0.0-0.20 m

\begin{tabular}{llllllll}
\hline Mesh $(\mathrm{mm})$ & 12.00 & 10.00 & 7.93 & 6.39 & 4.00 & 3.10 & $<3.10$ \\
\hline Weight $^{1}\left(\mathrm{~g} 1000 \mathrm{~g}^{-1}\right)$ & 4.24 & 6.636 & 38.75 & 103.27 & 362.4 & 159.4 & 325.35 \\
$\%$ & 0.42 & 0.66 & 3.87 & 10.33 & 36.24 & 15.94 & 32.54 \\
\hline
\end{tabular}

Note. ${ }^{1}$ The values refer to the weight of concretions retained in the sieves.

\subsection{Methods and Techniques}

Two treatments were obtained: soil with plinthite ironstone concretions and soil without these concretions. Soil samples were collected in the $0.0-0.20 \mathrm{~m}$ layer where fractions greater than $2 \mathrm{~mm}$ in diameter were removed according to the Manual of Soil Analysis Methods (Teixeira, Donagemma, Fontana, \& Teixeira, 2017) for physicochemical analysis. The textural analysis showed that the soil has $645 \mathrm{~g} \mathrm{~kg}^{-1}$ of sand, $50 \mathrm{~g} \mathrm{~kg}^{-1}$ of silt and $305 \mathrm{~g} \mathrm{~kg}^{-1}$ of clay. Based on the results of the chemical analysis, the soil was limed for Aluminium neutralization, $\mathrm{pH}$ elevation, Calcium and Magnesium supply (Goulding, 2016) in the quantity of limestone of $820 \mathrm{~kg} \mathrm{ha}^{-1}$. It was attempt to fertilize the experiments in a basic way, so that the plants had sufficient conditions to develop, since the objective was not to evaluate production, but the behavior of the species with the least possible interference of the fertilization and to stimulate the growth that could to reflect on the variables evaluated, since higher amounts of nutrients in the soil could mask the experiment.

The soil was fertilized based on the recommendation of Ribeiro, Guimarães, and Alvarez (1999) with $30 \mathrm{~kg} \mathrm{ha}^{-1}$ $\mathrm{N}$ with urea as the source, $120 \mathrm{~kg} \mathrm{ha}^{-1} \mathrm{P}_{2} \mathrm{O}_{5}$ whose source was single superphosphate and $90 \mathrm{~kg} \mathrm{ha}^{-1}$ of $\mathrm{K}_{2} \mathrm{O}$ with potassium chloride as the source. For the experiment, plastic pots with $18 \mathrm{~L}$ volume were filled with soil, making so two treatments: soil with ironstone concretions and soil without ironstone concretions. Each pot was seeded with five seeds per pot. The pots were placed on the ground, in a row, in free sky. Sowing occurred in December 2017 and five days after the emergency (DAE), thinning was done, leaving only one plant per pot. The irrigation was supplemented, every two days, so that the soil reached $80 \%$ of the field capacity. Each treatment (pots with 
and without ironstone concretions) had eight replications. An application of Thiamethoxam and Lambda-cyhalothrin ( $22 \mathrm{~mL}$ of active ingredient $\left.\mathrm{ha}^{-1}\right)$ at five DAE for control of the larvae (Liriomyza spp.) was performed. Caterpillars of the Spodoptera frugiperda type, when present, were removed with a long forceps, and therefore there were no insecticides against caterpillars. Morphological evaluation of height was conducted every three days, started since the hypocotyl emergence, measured from the soil to the tip of the last emerged leaf or ligule.

At 56 DAE, gas exchange were measured at 08:00, 10:00 a.m. and 04:00 p.m., among them: stomatal conductance $(\mathrm{gs})\left(\mathrm{mmol}\right.$ of $\left.\mathrm{H}_{2} \mathrm{O} \mathrm{m}^{-2} \mathrm{~s}^{-1}\right)$, net photosynthesis (A) $\left(\mu \mathrm{mol} \mathrm{m} \mathrm{m}^{-2}\right)$, transpiration $(\mathrm{E})\left(\mathrm{mmol}\right.$ of $\mathrm{H}_{2} \mathrm{O}$ $\left.\mathrm{m}^{-2} \mathrm{~s}^{-1}\right), \mathrm{CO}_{2}$ internal concentration rate $(\mathrm{iC})\left(\mathrm{mmol} \mathrm{CO} \mathrm{mol}^{-1}\right)$ and foliar temperature (Tleaf) $\left(\mathrm{C}^{\circ}\right)$ using an infrared gas analyzer (System ADC, Bioscientific Ltd. Hoddesdon, UK). The readings were performed on a leaf located in the middle third of the plant. These data were used to quantify the water use efficiency (WUE) and the instantaneous efficiency of the carboxylation (IEC) according to Cordão et al. (2018):

$$
\begin{aligned}
& \mathrm{WUE}=\mathrm{A} / \mathrm{E} \\
& \mathrm{IEC}=\mathrm{A} / \mathrm{Ci}
\end{aligned}
$$

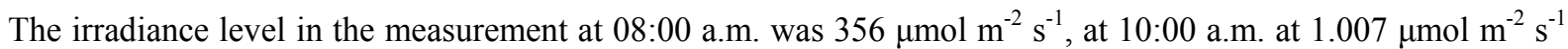
and at 04:00 a.m., $427 \mu \mathrm{mol} \mathrm{m} \mathrm{m}^{-2}$, where the measuring chamber covers a leaf area of $\operatorname{six~cm}^{2}(2 \times 3 \mathrm{~cm})$. Still at $56 \mathrm{DAE}$, the leaf chlorophyll index was evaluated based on the optical properties of the leaves with the aid of a chlorophyllometer (Falker Automação Agrícola, Brazil) therefore determined chlorophyll-a, chlorophyll-b and total chlorophyll values.

At 65 DAE, the experiment was terminated. The aerial part and the root system were separated. The shoot of the plants were dissected, followed by the measurement of: distance between nodes and width and length of the five largest leaves. Leaf area was obtained through the product of leaf width, leaf length and correction factor 0.75 according to Umair, Ilyas and Ikram (2014) and Musa and Usman (2016):

$$
\mathrm{LA}=\mathrm{LW} \times \mathrm{LL} \times 0.75
$$

Roots were washed in running water and both, root and aerial part, were placed in a drying oven with forced circulation at $65^{\circ} \mathrm{C}$ for $72 \mathrm{~h}$. The dry masses were then weighed on a precision scale to obtain root dry mass, dry shoot mass, total dry mass and root shoot ratio.

\subsection{Statistical Analysis}

The test for the verification of the normality of the data was not carried out, since it is not advisable to carry out the test on samples of sizes less than or equal to ten, but to proceed directly to a non-parametric analysis strategy (Torman, Coster, \& Riboldi, 2012; Le Boedec, 2016). The averages were compared using the Wilcoxon test for independent samples $\mathrm{p}<0.05$, using the ActionStat supplement (Estatcamp, 2014) for Excel (Microsoft, 2016). The factorial analysis were performed using the Kruskal-Wallis test $\mathrm{p}<0.05$, using the ActionStat supplement (Estatcamp, 2014) for Excel (Microsoft, 2016) as for dispersion graphs.

\section{Results and Discussion}

Figure 1 shows the average growth (in $\mathrm{cm}$ ) of maize plants (Zea mays) cultivated in soil with plinthite ironstone concretions and without concretions. It can be observed that maize grown in soil without ironstone concretions showed higher growth throughout the evaluation period.

The final mean height, measured at 65 DAE, was $128.37 \mathrm{~cm}$ in the plants cultivated in soil with ironstone concretions and $144.12 \mathrm{~cm}$ in those cultivated in soil without ironstone concretions. Singh and Hadda (2015) evaluated maize effect of different compaction levels of soil in a Cambisol with $67 \%$ of sand, $15 \%$ of silt and $16 \%$ of clay, and noticed that the height of maize plants was lower in the plots with compacted soil at 30,60 DAS (days after sowing) and during the harvest period.

Table 2 presents the values of gas exchange in maize plants (Zea mays), measured at three periods on a day, cultivated in soil with and without ironstone concretions. The stomatal conductance (gs), in the three measured times presented value with statistical difference. Maize cultivated in soil with ironstone concretions obtained lower values at 08:00 a.m. and 04:00 p.m., whereas at 10:00 a.m., maize cultivated in soil with ironstone concretions presented higher value. 


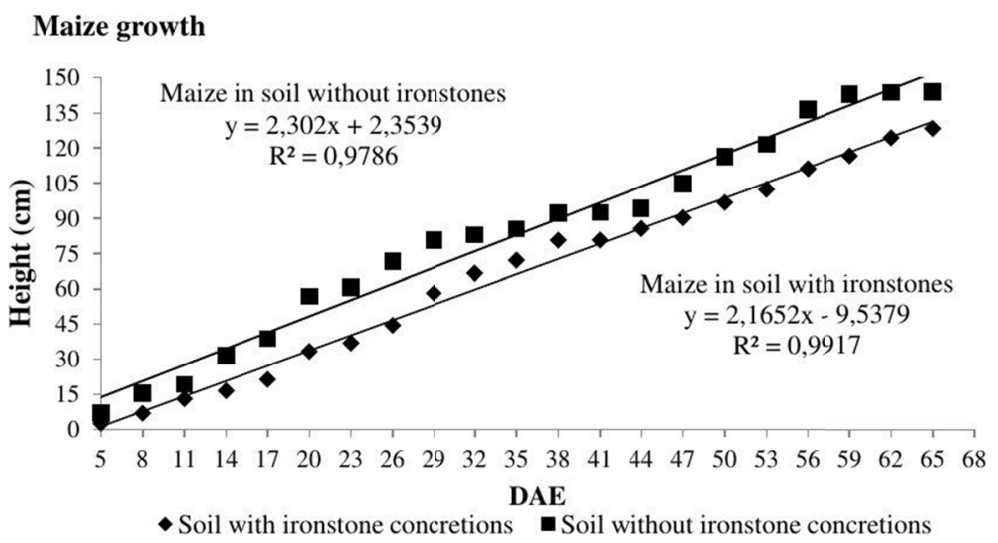

Figure 1. Average growth (in $\mathrm{cm}$ ) of maize plants (Zea mays) cultivated in soil with ironstone concretions and without ironstone concretions

Table 2. Means of stomatal conductance (gs), net photosynthesis (A), transpiration (E), $\mathrm{CO}_{2}$ internal concentration rate (iC), foliar temperature (Tleaf), water use efficiency (WUE) and instantaneous efficiency of carboxylation (IEC) measured in maize plants (Zea mays) at 56 DAE at 08:00, 10:00 a.m. and 04:00 p.m. cultivated in soil with and without ironstone concretions

\begin{tabular}{|c|c|c|c|c|c|c|}
\hline \multirow{2}{*}{$08: 00 a$. } & \multirow[t]{2}{*}{ Unit } & \multicolumn{2}{|c|}{ Soil with ironstone concretions } & \multicolumn{3}{|c|}{ Soil without ironstone concretions } \\
\hline & & & & & & \\
\hline gs & $\mathrm{mmol}$ of $\mathrm{H}_{2} \mathrm{O} \mathrm{m} \mathrm{m}^{-2} \mathrm{~s}^{-1}$ & 0.17 & b A & 0.28 & $\mathrm{a}$ & A \\
\hline A & $\mu \mathrm{mol} \mathrm{m}^{-2 \mathrm{~s}-1}$ & 7.44 & a $\mathrm{B}$ & 8.44 & $\mathrm{a}$ & $\mathrm{B}$ \\
\hline $\mathrm{E}$ & $\mathrm{mmol}$ of $\mathrm{H}_{2} \mathrm{O} \mathrm{m}^{-2} \mathrm{~s}^{-1}$ & 2.13 & $\mathrm{~b} \quad \mathrm{~B}$ & 2.69 & a & B \\
\hline $\mathrm{iC}$ & $\mathrm{mmol} \mathrm{CO}_{2} \mathrm{~mol}^{-1}$ & 310.36 & a A & 326.01 & a & A \\
\hline Tleaf & ${ }^{\circ} \mathrm{C}$ & 32 & a $\mathrm{C}$ & 31.93 & a & B \\
\hline WUE & & 3.62 & a $\mathrm{A}$ & 3.21 & $\mathrm{a}$ & $\mathrm{AB}$ \\
\hline IEC & & 0.024 & a $\mathrm{B}$ & 0.026 & a & $\mathrm{B}$ \\
\hline \multicolumn{7}{|c|}{ 10:00 a.m. } \\
\hline gs & $\mathrm{mmol}$ of $\mathrm{H}_{2} \mathrm{O} \mathrm{m}^{-2} \mathrm{~s}^{-1}$ & 0.30 & a A & 0.11 & $\mathrm{~b}$ & $\mathrm{~B}$ \\
\hline A & $\mu \mathrm{mol} \mathrm{m}{ }^{-2 \mathrm{~s}-1}$ & 22.76 & a A & 9.19 & $\mathrm{~b}$ & $\mathrm{AB}$ \\
\hline E & $\mathrm{mmol}$ of $\mathrm{H}_{2} \mathrm{O} \mathrm{m}^{-2} \mathrm{~s}^{-1}$ & 6.82 & a A & 3.88 & $\mathrm{~b}$ & A \\
\hline $\mathrm{iC}$ & $\mathrm{mmol} \mathrm{CO}_{2} \mathrm{~mol}^{-1}$ & 196.31 & a $\mathrm{B}$ & 248.10 & a & B \\
\hline Tleaf & ${ }^{\circ} \mathrm{C}$ & 38.92 & a A & 39.45 & $\mathrm{a}$ & A \\
\hline WUE & & 3.176 & a A & 2.415 & $\mathrm{a}$ & B \\
\hline IEC & & 0.136 & a A & 0.044 & $\mathrm{~b}$ & A \\
\hline \multicolumn{7}{|c|}{ 04:00 p.m. } \\
\hline gs & $\mathrm{mmol}$ of $\mathrm{H}_{2} \mathrm{O} \mathrm{m} \mathrm{m}^{-2} \mathrm{~s}^{-1}$ & 0.17 & b A & 0.26 & $\mathrm{a}$ & A \\
\hline $\mathrm{A}$ & $\mu \mathrm{mol} \mathrm{m}{ }^{-2 \mathrm{~s}-1}$ & 8.21 & b $B$ & 13.12 & $\mathrm{a}$ & A \\
\hline $\mathrm{E}$ & $\mathrm{mmol}$ of $\mathrm{H}_{2} \mathrm{O} \mathrm{m}^{-2} \mathrm{~s}^{-1}$ & 2.65 & $\mathrm{~b} \quad \mathrm{AB}$ & 3.22 & $\mathrm{a}$ & $\mathrm{AB}$ \\
\hline $\mathrm{iC}$ & $\mathrm{mmol} \mathrm{CO}_{2} \mathrm{~mol}^{-1}$ & 281.03 & a A & 259.73 & $\mathrm{~b}$ & B \\
\hline Tleaf & ${ }^{\circ} \mathrm{C}$ & 34.01 & a $\mathrm{B}$ & 33.46 & $\mathrm{~b}$ & B \\
\hline WUE & & 3.23 & $\mathrm{~b} \quad \mathrm{~A}$ & 4.49 & $\mathrm{a}$ & A \\
\hline IEC & & 0.03 & b $B$ & 0.053 & $\mathrm{a}$ & A \\
\hline
\end{tabular}

Note. Lowercase averages followed by equal letters in the row do not differ statistically from each other by the independent Wilcoxon test $\mathrm{p}<0.05$ and uppercase means followed by equal letters between the periods evaluated in each soil do not differ statistically from each other by the Kruskal-Wallis test $\mathrm{p}<0.05$.

The results show a drop in stomatal conductance throughout the day in maize grown without ironstone concretions and a recovery at the end of the day, which can be attributed to the intensity of the decrease in leaf water potential and subsequent normalization, by raising the temperature and irradiation (Figure 2) in the environment, its stomatal conductance (gs) decreased according to the measurement at 10:00 a.m and in the measurement at 04:00 p.m., although the high temperature $\left(28.6^{\circ} \mathrm{C}\right)$ raised the conductance, since the radiation declined sharply. The same could not be observed in maize cultivated with ironstone concretions, which maintained its stomatal conductance statistically equal. 


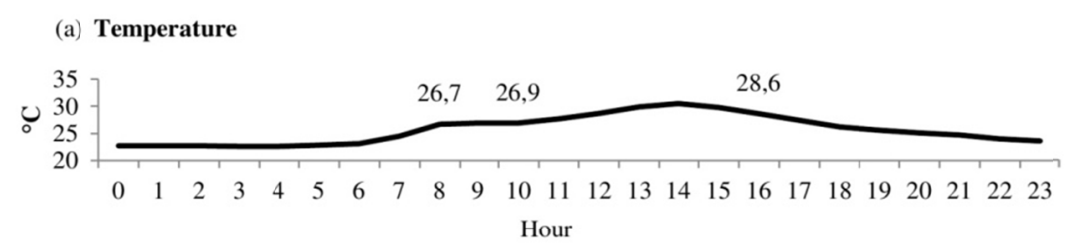

(b) Humidity

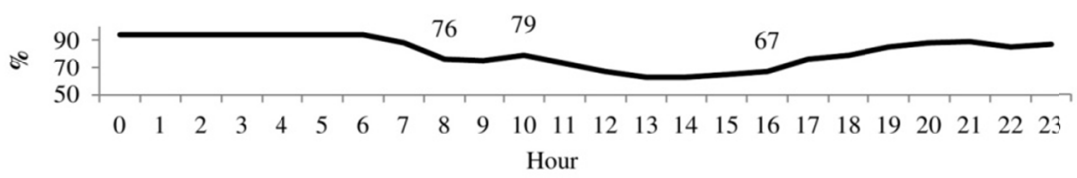

(c) Wind

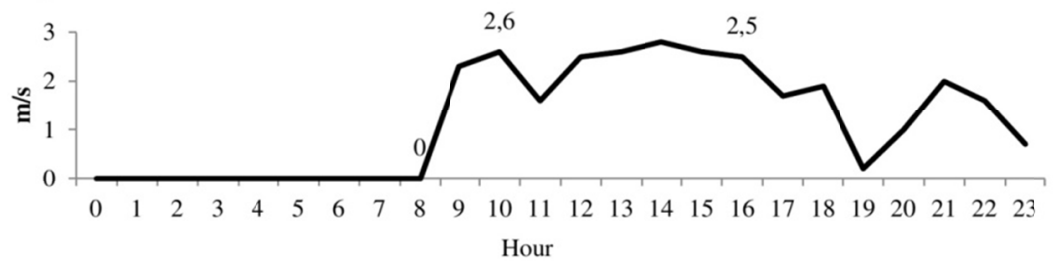

(d) Radiation

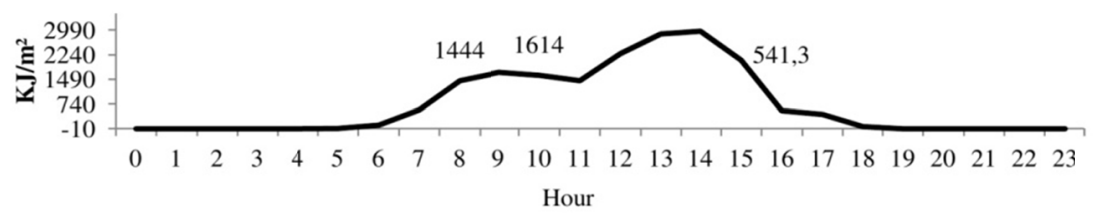

Figure 2. Oscillation of temperature (a), humidity (b), wind (c) and solar radiation (d) during the day of measurement of maize (Zea mays) gas exchange, grown in soil with and without ironstone concretions

(INMET, 2018)

The response of maize cultivated in soil without ironstone concretions was not expected, since the tendency is that the gs increase in the morning, oscillate during the hottest hours of the day and decrease at dusk, as reported by Lopes, Caruso Machado, Deuber and Silverio Machado (2009) when studying the growth and gas exchange of maize to the subsequent triticale planting in the no-till and conventional systems.

The value of net photosynthesis (A) (Table 2) had statistical difference in two periods, at 10:00 a.m. and 04:00 p.m. Maize cultivated in soil with ironstone concretions showed a higher value of A at 10:00 a.m., while at 04:00 p.m., maize cultivated in soil without ironstone concretions, presented higher value. The maize cultivated in soil with ironstone concretions had an expressive peak of liquid photosynthesis in the measurement at 10:00 a.m., possibly contributed by the greater stomatal conductance observed in that time, which can be reinforced by the value observed at the measurement at 04:00 p.m., with a strong decrease. In maize grown on soil without ironstone concretions, the value was increasing, even with lower gs, observed in the measurement at 10:00 a.m., increasing further at 04:00 p.m., probably due to the greater stomatal conductance observed. Pereira, Bergonci, Bergamaschi, Rosa, and França (2003) studied maize submitted to different levels of water in the soil, in a Red Argisoil in a greenhouse, measured the photosynthesis, at 38,52 and 65 DAE, and observed in all the dates lower value of net photosynthesis measured in the units with lower water availability.

The transpiration (E) (Table 2), showed statistical difference in the three measured periods. At 8:00 a.m. and 04:00 p.m., the maize cultivated in the soil with ironstone concretions presented a lower value with a statistical difference, while at 10:00 a.m. the maize cultivated in soil without ironstone concretions presented a lower value of $\mathrm{E}$.

Maize cultivated in soil with ironstone concretions, as well as in photosynthesis, had an expressive peak of transpiration in the measurement at 10:00 a.m., also possibly contributed by the greater stomatal conductance and liquid photosynthesis observed at that time, and that can also be reinforced by the value observed in the measurement at 04:00 p.m., with moderate decrease. In maize grown in soil without ironstone concretions, values were increasing, in the measurement at 08:00 and 10:00 a.m., and decreasing at 04:00 p.m. An explanation for the value in the last measurement being smaller than in the previous one, may have been due to 
lower radiation recorded at the measurement time (Figure 2) which may have contributed to the plant also reducing its transpiration.

Magalhães et al. (2009) characterized contrasting maize strains in terms of resistance to drought in the full flowering stage, through gas exchange, including transpiration, in $20 \mathrm{~L}$ pots with Red Oxisol at a greenhouse and observed statistically lower value in maize grown in soil in a restrictive environment, in this case, water deficit.

The internal $\mathrm{CO}_{2}$ concentration (iC) (Table 2) had a statistical difference between treatments in only one evaluated period. At 04:00 p.m. the maize cultivated in soil with ironstone concretions presented higher value of $\mathrm{iC}$ than the maize cultivated in soil without ironstone concretions.

Maize cultivated in soil with ironstone concretions showed a decrease of its internal $\mathrm{CO}_{2}$ concentration (iC) in the measurement at 10:00 a.m. and recovery at 04:00 p.m. Similar behavior could be seen in maize cultivated in soil without ironstone concretions, decrease at 10:00 a.m. but unlike maize cultivated in soil with ironstone concretions, did not recover in the measurement at 04:00 p.m., remaining statistically equal to the measurement at 10:00 a.m. The stomatal opening is induced by lower value of internal $\mathrm{CO}_{2}$ concentration, high light intensity and high humidity, according to Araújo, Fernie, and Nunes-Nesi (2011), higher concentrations of $\mathrm{CO}_{2}$, low luminosity, water deficit and plant hormone ABA induce its closure, which could be observed in the maize cultivated in soil with ironstone concretions measured at 10:00 a.m., where a lower value of $\mathrm{iC}$ was observed but presented higher value of net photosynthesis.

Regarding leaf temperature (Tleaf) (Table 2), there was a significant difference only in one period evaluated. Maize cultivated in soil with ironstone concretions presented higher value at 04:00 p.m. Taiz, Zeiger, Møller, and Murphy (2017) commented that less stomatal conductance and lower transpiration causes an increase in leaf temperature, which was partially observed in this study, since at 10:00 a.m. the maize cultivated in soil with ironstone concretions presented higher gs and $\mathrm{E}$ in relation to maize cultivated in soil without ironstone concretions.

The value of water use efficiency (WUE) (Table 2) had statistical difference only in one period evaluated, at 04:00 p.m. the maize cultivated in soil with ironstone concretions presented lower value in relation to the maize cultivated in soil without ironstone concretions. Maize cultivated in soil without ironstone concretions, showed WUE of 4.49, while maize cultivated in soil with ironstone concretions presented a value of 3.23. Among the treatments, there was no statistically significant difference in maize cultivated in soil with ironstone concretions, while in maize cultivated in soil without ironstone concretions, the efficiency decreased in the measurement at 10:00 a.m., but it increased again at 04:00 p.m. In the maize cultivated in soil without ironstone concretions, at 04:00 p.m. photosynthesis was greater, as well as transpiration, which reflected in WUE and showed a statistical difference.

Ribeiro, Barbosa, Lopes, Pereira, and Albuquerque (2018) commented that the relationship between photosynthesis and transpiration determines the instantaneous efficiency in the use of water, meaning, the amount of carbon that the plant fixes, for each unit of water it loses. Magalhães et al. (2009) in a work of characterization of contrasting maize lineages regarding the resistance to drought, perceived higher value in maize with water deficiency.

Values of instantaneous efficiency of the carboxylation (IEC) (Table 2) had statistical difference in two periods of evaluation. At 10:00 a.m., maize cultivated in soil with ironstone concretions presented higher value and at 04:00 p.m. maize cultivated in soil without ironstone concretions presented higher value of IEC. The value shows IEC oscillation throughout the day. In maize grown on ironstone concretions soil, IEC increased with increasing radiation at 10:00 a.m., possibly due to increased ATP and NADPH production required for $\mathrm{CO}_{2}$ fixation in the Calvin cycle and decreased dramatically at 04:00 p.m. The photosynthetic apparatus is protected by photorespiration in situations of excessive radiation or environmental stress, biotic and abiotic (Machado, Schmidt, Medina, \& Ribeiro, 2005) what may have happened in this case, environmental stress by abiotic factors. On the other hand, the maize cultivated in soil without ironstone concretions increased its efficiency at 10:00 a.m. and remained stable to 04:00 p.m.

Table 3 shows the value of leaf chlorophyll index (LCI) measured in maize plants grown in soil with and without ironstone concretions. There was a statistical difference in all evaluated variables where the value was higher in maize grown in soil without ironstone concretions. In relation to chlorophyll-a, maize cultivated in soil with ironstone concretions presented a value of 18.83 , while maize cultivated in soil without ironstone concretions showed a value of 29.33 . 
Table 3. Leaf chlorophyll index (LCI) averages of chlorophyll-a, chlorophyll-b and total chlorophyll in maize (Zea mays) grown in soil with and without ironstone concretions

\begin{tabular}{llll}
\hline & Chlorophyll-a & Chlorophyll-b & Total chlorophyll \\
\hline Soil with ironstone concretions & $18.83 \mathrm{~b}$ & $05.31 \mathrm{~b}$ & $24.15 \mathrm{~b}$ \\
Soil without ironstone concretions & $29.33 \mathrm{a}$ & $11.05 \mathrm{a}$ & $40.38 \mathrm{a}$ \\
\hline
\end{tabular}

Note. Means followed by equal letters in the column do not differ statistically from each other by independent Wilcoxon test $\mathrm{p}<0.05$; Variation Coefficient: chlorophyll-a, 25\%, chlorophyll-b, 41\%, total chlorophyll, $29 \%$.

The levels of chlorophyll and carotenoids in the leaves are used to estimate the photosynthetic potential of plants (Rego \& Possamai, 2006), thus, the contents and composition of these organelles can be used as indicative parameters of stress in plants (Codognotto et al., 2002), since the greater reduction of chlorophyll content is a defense mechanism because it reduces the capture of light energy and thus decreases the flow of electrons to the electron transfer chain, since this is highly reduced favoring the partial reduction of the oxygen that results in the formation of reactive oxygen species (Willadino, Oliveira Filho, Silva Júnior, Gouveia Neto, \& Camara, 2011). Magalhães et al. (2009) in a work of characterization of contrasting maize lineages regarding the resistance to drought, perceived higher value in maize without water deficiency.

In spite of the fact that it was done only at 56 DAE, observing the value found in the measurement of chlorophyll, it is possible to make a brief relation with the growth of plants, observed in Figure 1, higher growth of maize grown in soil without ironstone concretions throughout the evaluation period, which may be an indication that the maize cultivated in soil with ironstone concretions suffered some type of stress.

Table 4 shows averages of morphological variables of maize plants grown in soil with and without ironstone concretions, where the plant height, length and width of the five largest leaves of the plants were measured, and the leaf area was then calculated.

Table 4. Means of distance between nodes, leaf width and leaf length (in $\mathrm{cm}$ ), calculated leaf area (LA) (in $\mathrm{cm}^{2}$ ) of maize (Zea mays) cultivated in soil with and without plinthite ironstone concretions

\begin{tabular}{lllll}
\hline & Internode distance & Leaf width & Leaf lenght & LA \\
\hline Soil with ironstone concretions & $8.9 \mathrm{a}$ & $6.18 \mathrm{a}$ & $59.1 \mathrm{a}$ & $273.96 \mathrm{a}$ \\
Soil without ironstone concretions & $9.6 \mathrm{a}$ & $6.39 \mathrm{a}$ & $59.9 \mathrm{a}$ & $290.69 \mathrm{a}$
\end{tabular}

Note. Means followed by equal letters in the column do not differ statistically from each other by independent Wilcoxon test $\mathrm{p}<0.05$; Variation Coefficient: internode distance, 10\%, width, $11 \%$, lenght, $11 \%$, LA, 19\%.

There was no statistical difference in any of the evaluated variables. Evaluations of these variables are interesting, since they can indicate greater or lesser leaf area to capture light and later transform it into energy for the plant. According to Mondo, De Carvalho, Labonia, Neto, and Cicero (2009), the mathematical equations that correlate the length and width of leaves with real area are efficient estimators of the foliar development of maize plants.

Table 5 shows the mean (in g) of dry mass of the aerial part (DMA), dry mass of the root part (DMR), total dry mass (TDM) and shoot root ratio (DMA DMR ${ }^{-1}$ ) of maize grown in soil with and without concretions of plinthite ironstones, with the weight of spikes of maize under development added to the calculation and without adding them. There was a statistically difference in shoot size only when the weight of growing spikes of maize were added, with higher value for maize cultivated in soil without ironstone concretions. The spikes were in development, in the phenological stage VT, with developing tassel. 
Table 5. Means of dry mass of the aerial part (DMA), dry mass of the root (DMR), total dry mass (TDM) and shoot root ratio (MSA $\mathrm{MSR}^{-1}$ ) of maize (Zea mays) calculated with and without maize spikes in development, cultivated in soil with and without ironstone concretions

\begin{tabular}{llllc}
\hline & DMA & DMR & TDM & MSA MSR $^{-1}$ \\
\hline Without spike & & & & \\
Soil with ironstone concretions & $65.8 \mathrm{a}$ & $35.6 \mathrm{~b}$ & $101.4 \mathrm{~b}$ & $1.9 \mathrm{a}$ \\
Soil without ironstone concretions & $74.9 \mathrm{a}$ & $54.8 \mathrm{a}$ & $129.8 \mathrm{a}$ & $1.4 \mathrm{~b}$ \\
\hline With spike & & & & \\
Soil with ironstone concretions & $65.8 \mathrm{~b}$ & $35.6 \mathrm{~b}$ & $101.4 \mathrm{~b}$ & $1.9 \mathrm{a}$ \\
Soil without ironstone concretions & $112.7 \mathrm{a}$ & $54.8 \mathrm{a}$ & $167.6 \mathrm{a}$ & $2.1 \mathrm{a}$ \\
\hline
\end{tabular}

Note. Means followed by equal letters in the column do not differ statistically from each other by independent Wilcoxon test $\mathrm{p}<0.05$; Variation Coefficient: without spike, DMA, 17\%, DMR, 33\%, TDM, 20\%, DMA $\mathrm{DMR}^{-1}, 25 \%$; with spike, DMA, 30\%, DMR, 33\%, TDM, 29\%, DMA DMR ${ }^{-1}, 19 \%$.

Regarding the root dry matter, there was a statistical difference between the treatments. Maize cultivated in soil without ironstone concretions presented a higher value, when compared to the maize cultivated in the soil with ironstone concretions. For total dry mass, with and without maize spikes added on the calculation, higher value for maize grown in soil without ironstone concretions too. Regarding the dry mass ratio of shoot and root, there was statistical difference only when the spike was left out of the calculation, with the maize cultivated in the soil with ironstone concretions presenting higher ratio.

The fact that the DMA DMR ${ }^{-1}$ ratio is different when calculated without spike can be explained by the fact that some of the photoassimilates produced by maize grown in soil without ironstone concretions are directed to the development of the spike, whereas in maize grown in soil with ironstone concretions there is still a strong direction of photoassimilates for leaves, stems and roots, which may be an indication that the maize cultivated in soil with ironstone concretions suffered some type of stress and therefore delayed the evolution of the phenological stages of the crop.

Considering the results of root, aerial and total dry mass averages, and in a relationship with other evaluated variables, it is possible to observe that there was a certain difficulty of maize cultivated in soil with ironstone concretions to develop satisfactorily according to its physiological potential, as observed in maize cultivated in soil without ironstone concretions, regardless of whether it reached its maximum physiological potential or not and it would certainly betray consequences in later phenological stages. Freddi et al. (2007) reported a decrease in the dry mass of the maize as the compaction, root restriction environment, of the soil was accentuated, in an experiment with Red Oxisol of medium texture, which later reflected on yield.

\section{Conclusion}

Plinthite ironstone concretions interfere with the growth and/or vegetative development of maize.

Maize has its gas exchanges altered due to soil cultivation with ironstone concretions.

Maize has lower plant development, reflected in height, dry mass and delay of its phenological stage, when cultivated in soil with ironstone concretions.

\section{References}

Amorim Da Silva, D., Alves De Albuquerque, J. D. A., Alves, A., Maria, J., Ribeiro Rocha, P. R., Dantas De Medeiros, R., ... Santos De Menezes, P. H. (2018). Characterization of weed in rotated area of maize and cowpea in direct planting. Scientia Agropecuaria, 9, 7-15. https://doi.org/10.17268/sci.agropecu.2018.01.01

Araújo, W. L., Fernie, A. R., \& Nunes-Nesi, A. (2011). Control of stomatal aperture: A renaissance of the old guard. Plant, Signaling \& Behavior, 6, 1305-1311. https://doi.org/10.4161/psb.6.9.16425

Azevedo, J. R., \& Bueno, C. R. P. (2017). Potencialidades e limitações agrícolas de solos em assentamento de reforma agrária no município de Chapadinha-MA. Scientia Agraria, 17, 1-13. https://doi.org/10.5380/ rsa.v17i3.46841

Benincasa, M. P. (2003). Análise de crescimento de plantas (p. 41). Jaboticabal: Funep.

Chesworth, W. (2008). Encyclopedia of Soil Science. Encyclopedia of Earth Sciences Series (p. 860). Dordrecht: Springer. https://doi.org/10.1007/978-1-4020-3995-9 
Codognotto, L. M., Santos, D. M. M., Leite, I. C., Marin, A., Madaleno, L. L., Kobori, N. N., \& Banzatto, D. (2002). Efeito do alumínio nos teores de clorofilas de plântulas de feijão-mungo e labe-labe. Ecossistema, 27, 27-30.

Cordão, M. A., Araújo, W. P., Pereira, J. R., Zonta, J. H., De Lima, R. F., \& Ferreira, F. N. (2018). Upland cotton cultivars under water deficit applied in phenological phases. Revista Verde de Agroecologia e Desenvolvimento Sustentável, 13, 313-321. https://doi.org/10.18378/rvads.v13i3.5933

Dos Santos, H. G., Jacomine, P. K. T., dos Anjos, L. H. C., de Oliveira, V. A., Lumbreras, J. F., Coelho, M. R., ... Cunha, T. J. F. (2018). Sistema brasileiro de classificação de solos (5th ed., p. 353). Brasília: EMBRAPA.

Dos Santos, C. C. M. (2018). Matopiba: uma nova fronteira agrícola? Uma conciliação geográfica de ordenamento do agronegócio? Uma nova reorganização produtiva dos espaços de "cerrados" dos estados do Maranhão, Tocantins, Piauí e Bahia? Cadernos do CEAS: Revista crítica de humanidades, 245, 570-600. https://doi.org/ 10.25247/2447-861X.2018.n245.p590-623

Dubreuil, V., Fante, K. P., Planchon, O., \& Neto, J. L. S. A. (2018). Les types de climats annuels comme marqueurs du changement climatique au Brésil de 1964 a 2015. Revue franco-brésilienne de géographie, 37, 406-411.

Estatcamp. (2014). Software Action. Estatcamp, Consultoria em Estatística e Qualidade, São Carlos.

Freddi, O. D. S., Centuron, J. F., Beutler, A. N., Aratani, R. G., Leonel, C. L., \& Silva, Á. P. D. (2007). Soil compaction and least limiting water range on developmentand productivity of maize. Bragantia, 66, 477-486. https://doi.org/10.1590/S0006-87052007000300015

Garcia, J. R., \& Vieira Filho, J. E. R. (2017). A questão ambiental ea expansão da fronteira agrícola na direção do Matopiba brasileiro (p. 71). Brasília: IPEA.

Goulding, K. W. T. (2016). Soil acidification and the importance of liming agricultural soils with particular reference to the United Kingdom. Soil Use and Management, 32, 390-399. https://doi.org/10.1111/ sum. 12270

INMET (Instituto Nacional de Meteorologia). (2018). Estação Meteorológica de Observação de Superficie Automática. Retrieved from http://www.inmet.gov.br/portal/index.php?r=estacoes/estacoesAutomaticas

Le Boedec, K. (2016). Sensitivity and specificity of normality tests and consequences on reference interval accuracy at small sample size: A computer - simulation study. Veterinary Clinical Pathology, 45, 648-656. https://doi.org/10.1111/vcp.12390

Long, S. P., \& Bernacchi, C. J. (2003). Gas exchange measurements, what can they tell us about the underlying limitations to photosynthesis? Procedures and sources of error. Journal of Experimental Botany, 54, 2393-2401. https://doi.org/10.1093/jxb/erg262

Lopes, J. P., Caruso Machado, E., Deuber, R., \& Silverio Machado, R. (2009). Growth analysis and gas exchanges in corn cultivated in no tillage and conventional cropping. Bragantia, 68, 839-848. https://doi.org/10.1590/ S0006-87052009000400003

Machado, E. C., Schmidt, P. T., Medina, C. L., \& Ribeiro, R. V. (2005). Photosynthetic responses of three citrus species to environmental factors. Pesquisa Agropecuária Brasileira, 40, 1161-1170. https://doi.org/10.1590/ S0100-204X2005001200002

Magalhães, P. C., De Souza, T. C., De Albuquerque, P. E. P., Karam, D., Magalhães, M. M., \& Cantão, F. R. D. O. (2009). Ecophysiological characterization of maize lines submitted to low water availability during flowering. Revista Brasileira de Milho e Sorgo, 8, 223-232. https://doi.org/10.18512/1980-6477/rbms.v8n3p223-232

Microsoft. (2016). Microsoft Office Excel v.16.0. Microsoft Corporation, One Microsoft Way, Redmond.

Mondo, V. H. V., De Carvalho, S. J. P., Labonia, V. D. D. S., Neto, D. D., \& Cicero, S. M. (2009). Comparison of methods for estimating leaf area on maize. Revista Brasileira de Milho e Sorgo, 8, 233-246. https://doi.org/ 10.18512/1980-6477/rbms.v8n3p233-246

Musa, U. T., \& Usman, T. H. (2016). Leaf area determination for maize (Zea mays L.), okra (Abelmoschus esculentus L.) and cowpea (Vigna unguiculata L.) crops using linear measurements. Journal of Biology, Agriculture and Healthcare, 6, 103-111.

Nikkel, M., \& Lima, S. O. (2017). Spatial distribution of soil organic matter under the use of different center pivots. Acta Iguazu, 6, 56-64. 
Oliveira, J. B. (2008). Pedologia Aplicada (3rd ed., p. 592). Piracicaba: FEALQ.

Peixoto, C. P., Cruz, T. V., Peixoto, M. F. S. (2011). Análise quantitativa do crescimento de plantas: conceitos e prática. Enciclopédia Biosfera, 7, 51-76.

Pereira, P. G., Bergonci, J. I., Bergamaschi, H., Rosa, L. M. G., \& França, S. (2003). Effects of different levels of water deficit on photosynthesis and leaf conductance in mayze. Revista Brasileira de Agrometeorologia, 11, 53-62.

Rego, G. M., \& Possamai, E. (2006). Effect of shadeness over chlorophyll level and initial growth of Cariniana legalis. Pesquisa Florestal Brasileira, 53, 179-194.

Ribeiro, A. C., Guimarães, P. T. G., \& Alvarez V., V. H. (1999). Recomendações para o uso de corretivos e fertilizantes em Minas Gerais: 5. Aproximação (p. 359). Viçosa: CFSEMG (Comissão de Fertilidade do Solo do Estado de Minas Gerais).

Ribeiro, J. E. D. S., Barbosa, A. J. S., Lopes, S. D. F., Pereira, W. E., \& Albuquerque, M. B. D. (2018). Seasonal variation in gas exchange by plants of Erythroxylum simonis Plowman. Acta Botanica Brasilica, 32, 287-296. https://doi.org/10.1590/0102-33062017abb0240

Sauer, S., \& Leite, S. P. (2012). Expansão agrícola, preços e apropriação de terra por estrangeiros no Brasil. Revista de Economia e Sociologia Rural, 50, 503-524. https://doi.org/10.1590/S0103-20032012000300007

SEPLAN (Secretaria do Planejamento e Orçamento do Tocantins). (2015). Produto cartográfico, solos do Tocantins (6th ed., p. 80). Palmas: Seplan.

Silva, A. R. P., Almeida, M. G. (2007). O agronegócio e o Estado do Tocantins: o atual estágio de consolidação. Caminhos de Geografia, 8, 28-45.

Silva, L. C., Beltrão, N. D. M., \& Amorim Neto, M. D. S. (2000). Análise do crescimento de comunidades vegetais (p. 18). Campina Grande: EMBRAPA.

Singh, J., \& Hadda, M. S. (2015). Maize (Zea mays L.) response to subsoil compaction and nitrogen fertilization under semi-arid irrigated conditions. Journal of Applied and Natural Science, 7, 493-500. https://doi.org/ 10.31018/jans.v7i1.638

Taiz, L., Zeiger, E., Møller, I. M., Murphy, A. (2017). Fisiologia e desenvolvimento vegetal (6th ed., p. 888). Porto Alegre: Artmed.

Teixeira, P. C., Donagemma, G. K., Fontana, A. Teixeira, W. G. (2017). Manual de métodos de análise de solo (3rd ed., p. 573). Brasília: EMBRAPA.

Torman, V. B. L., Coster, R., Riboldi, J. (2012). Normality of variables: Diagnosis methods and comparison of some nonparametric tests by simulation. Revista Hospital das Clínicas de Porto Alegre, 32, 227-234.

Umair, M., Ilyas, U., \& Ikram, S. (2014). Morphological variations in maize (Zea mays L.) under different levels of $\mathrm{Na}_{2} \mathrm{SO}_{4}$ at growth stage. Advance Research in Agriculture and Veterinary Science, 1, 72-77.

USDA (United States Department of Agriculture). (1999). Soil Taxonomy-A Basic System of Soil Classification for Making and Interpreting Soil Surveys (2nd ed., p. 889). Washington: United States Department of Agriculture.

Willadino, L., Oliveira Filho, R. A., Silva Junior, E. A., Gouveia Neto, A., \& Camara, T. R. (2011). Salinity stress in two varieties of sugar cane: Enzymes of the antioxidant system and chlorophyll fluorescence. Revista Ciência Agronômica, 42, 417-422. https://doi.org/10.1590/S1806-66902011000200022

\section{Copyrights}

Copyright for this article is retained by the author(s), with first publication rights granted to the journal.

This is an open-access article distributed under the terms and conditions of the Creative Commons Attribution license (http://creativecommons.org/licenses/by/4.0/). 